\title{
FMF in heterozygotes: are we able to accurately diagnose the disease in very young children?
}

\author{
Véronique Hentgen ${ }^{*}$, Katia Stankovic Stojanovic, Gilles Grateau, Serge Amselem, Isabelle Jeru \\ From 18th Pediatric Rheumatology European Society (PReS) Congress \\ Bruges, Belgium. 14-18 September 2011
}

\section{Background}

Reports of heterozygous carriers of a $M E F V$ mutation presenting a FMF phenotype are increasing, but no data is available on the outcome of FMF heterozygous children.

\section{Aim}

To assess the relevancy of clinical diagnosis of FMF in heterozygous children before the age of 6 .

\section{Methods}

We performed a retrospective single-centre study of 29 patients diagnosed with FMF before the age of 6, who had only 1 mutation in the $M E F V$ gene, compared to a group of 26 homozygous or compound heterozygous patients in whom the diagnosis of FMF was also made during early childhood.

\section{Results}

Presenting signs in heterozygous children did not differ from homozygous or compound heterozygous patients. Initial response to colchicine was identical in the two groups. During follow-up heterozygous patients were more likely to have a milder course of the disease. After puberty clinical signs of FMF totally disappeared in 6/11 heterozygous patients. In these 6 patients, colchicine could be withdrawn without recurrence of symptoms or rise of inflammatory markers. If applied after puberty, clinical diagnostic criteria sets were no longer positive in these 6 patients, whereas the same criteria applied retrospectively during early childhood concluded to FMF.

\footnotetext{
* Correspondence: vhentgen@ch-versailles.fr

French Reference Centre for Auto-Inflammatory Diseases (CeRéMAI),

Versailles Hospital, 177, rue de Versailles, 78150 Le Chesnay Cedex, France
}

\section{Conclusion}

Our study suggests that the diagnosis of FMF in very young heterozygous children should be cautious. Heterozygous children can present with an FMF-like disease during early childhood that may disappear with age, while others will suffer lifelong from their disease. Only a careful follow-up of FMF heterozygotes allows an accurate diagnosis over time.

Published: 14 September 2011

doi:10.1186/1546-0096-9-S1-P17

Cite this article as: Hentgen et al:: FMF in heterozygotes: are we able to accurately diagnose the disease in very young children? Pediatric Rheumatology 2011 9(Suppl 1):P17.
Submit your next manuscript to BioMed Central and take full advantage of:

- Convenient online submission

- Thorough peer review

- No space constraints or color figure charges

- Immediate publication on acceptance

- Inclusion in PubMed, CAS, Scopus and Google Scholar

- Research which is freely available for redistribution
C Biomed Central 